\title{
Morphometric analysis of human sacra
}

\author{
Anant Karbhari Shingare ${ }^{1^{*}}$, N B Masaram², S S Dhapate ${ }^{3}$ \\ ${ }^{1}$ Assistant Professor, ${ }^{3}$ Professor and HOD, Department of Anatomy, S.R.T.R. Government Medical College, Ambajogai, Maharashtra, INDIA. \\ ${ }^{2}$ Assistant Professor, Department of Anatomy, Dr Vaishampayan Memorial Government Medical College, Solapur, Maharashtra, INDIA. \\ Email: anant.karbhari@gmail.com, masaramnitin9@gmail.com
}

\begin{abstract}
Background: Sacrum is formed by fusion of five sacral vertebrae and forms the caudal end of the vertebral column. Anatomists and anthropologists since long acknowledged the importance of sacrum in identifying the sex of a deceased person. Sexual dimorphic characters can be studied both morphologically and metrically. Material and Methods: The present study was performed at Department of Anatomy, S. R. T. R. Government Medical College, Ambajogai, Maharashtra on 50 (25 male and 25 female) adult human sacra of known sex. Following equipments used were Sliding verniercaliper, divider, steel Measuring Scale. Parameters studied were Maximum length of sacrum, Maximum breadth of sacrum, Sacral index. Aims and Objective: This study was conducted to determine sexual dimorphism of adult sacrum, to evaluate the most significant parameter in sexual dimorphism and also to compare and contrast the result of present study with previous studies. Results and Conclusion: Ventral straght length and sacral index was found to be highly significant with a $p$ value of $<0.0001$. Maximum breadth was found to be not significant with a value of $<0.0566$.From the present study we find out similarities and differences in the metrical values of different sacral parameters in males and females and also highlighted the best parameter which can be used for sexual dimorphism of sacrum.
\end{abstract}

Key Words: Morphometric, human sacra.

*Address for Correspondence:

Dr. Anant Karbhari Shingare, Assistant Professor, S.R.T.R. Government Medical College, Ambajogai, Maharashtra, INDIA.

Email: anant.karbhari@gmail.com

Received Date: 12/06/2017 Revised Date: 10/07/2017 Accepted Date: 03/08/2017

DOI: https://doi.org/10.26611/1001321

\begin{tabular}{|l|l|}
\hline \multicolumn{2}{|c|}{ Access this article online } \\
\hline Quick Response Code: & Website: \\
\hline & www.medpulse.in \\
\hline & \\
\hline
\end{tabular}

\section{INTRODUCTION}

Sacrum is formed by fusion of five sacral vertebrae and forms the caudal end of the vertebral column. The sacrum supports the erect spine, provides the strength and stability to the bony pelvis in transmitting body weight. The bones of body are the last to perish after death next only to the enamel of teeth. Determination of sex is an integral first step in the development of the biological profile in human osteology. Sex determination is necessary to make age, ancestry and stature estimations, as the sex's age differently, exhibit some degree of variation in ancestry related morphology and generally differ in height. (Kothapalli). Anatomists and anthropologists since long acknowledged the importance of sacrum in identifying the sex of a deceased person.

\section{MATERIALS AND METHODS}

The present study was performed on 50 (25 male and 25 female) adult human sacra of known sex. All of them were dry and free from deformity and fully ossified. All the sacra were obtained from Department of Anatomy, S.R.T.R. Government Medical College, Ambajogai, Maharashtra Following equipments were used for measurement of various parameters.

1. Sliding vernier caliper

2. Divider

3. Steel Measuring Scale

Each sacrum was studied for different features of sexual dimorphism and sacral hiatus.

\section{Sexual dimorphism}

1. Maximum length of sacrum (Ventral straight length): With the help of vernier calliper straight length measured between the distance from the middle of the anterosuperior margin of sacral promontory in the mid sagittal plane to the 
middle of anteroinferior margin of the last sacral vertebra.

2. Maximum breadth of sacrum: With the help of vernier calliper maximum distance was noted by midpoint of left and right alae of sacrum.

3. Sacral index: Sacral Index for each sacrum was calculated as follows:

Sacral index $=($ sacral width $/$ sacral ventral straight length) $\mathrm{x} 100$. After completing measurements, they were tabulated and statistically analysed with the help of SPSS software. Mean, standard deviation, range, demarking points and percentage of identified bones calculated.

\section{RESULTS}

At the first of study, each parameter were tabulated and statistically analyzed. Comparative graphs of male and female values were drawn which shows the zone of difference and overlapping between male and female values.
The ventral straight length: The ventral straight length was found to be having a mean of 104.73 in males and 92.64 in females. The demarking points for males was $>110.94$ and $<86.91$ in females.

This parameter was helpful in identification of $16.86 \%$ of bones in males and $19.30 \%$ of bones in females. Ventralstraght length was found to be highly significant with a $p$ value of $<0.0001$

The maximum breadth: The maximum breadth was found to be having a mean of $102.93 \mathrm{~mm}$ in males and $104.77 \mathrm{~mm}$ in females. The demarking points for males was $>124.21$ and $<88.44$ in females.

Maximum breadth was found to be not significant with a $\mathrm{p}$ value of $<0.0566$.

Sacral Index: The sacral index was found to be having a mean of $98.44 \mathrm{~mm}$ in males and $113.23 \mathrm{~mm}$ in females. The demarking points for males was $<96.4$ and $>112.51$ in females. This parameter was helpful in identification of $27.71 \%$ of bones in males and $57.9 \%$ of bones in females. Sacral index was found to be highly significant with a $\mathrm{p}$ value of $<0.0001$.

Table 1: Showing measurements of Ventral straight length, Maximum breadthand sacral index in males and females

\begin{tabular}{|c|c|c|c|c|c|c|}
\hline & \multicolumn{2}{|c|}{ Ventral straight length } & \multicolumn{2}{|c|}{ Maximum breadth } & \multicolumn{2}{|c|}{ Sacral Index } \\
\hline & Male & Female & Male & Female & Male & Female \\
\hline No. of bone & 25 & 25 & 25 & 25 & 25 & 25 \\
\hline sRange & $90.35-120.78$ & $81-110.64$ & $92.65-115.65$ & $88.98-126.54$ & 86.78 to 116.09 & 99.13 to 123.10 \\
\hline Mean & 104.73 & 92.64 & 102.93 & 104.77 & 98.44 & 113.23 \\
\hline Standard deviation (S.D.) & 5.94 & 6.1 & 4.83 & 6.48 & 4.69 & 5.61 \\
\hline Mean \pm 3 S.D. & $86.91-122.55$ & $74.34-110.94$ & $88.44-117.42$ & $85.33-124.21$ & 84.37 to 112.51 & 96.4 to 130.06 \\
\hline Demarking points & $>110.94$ & $<86.91$ & $>124.21$ & $<88.44$ & $<96.4$ & $>112.51$ \\
\hline Percentage of bone identified & 16.86 & 19.3 & - & - & 22.17 & 57.9 \\
\hline t value & \multicolumn{2}{|c|}{11.71} & \multicolumn{2}{|c|}{1.923} & \multicolumn{2}{|c|}{16.93} \\
\hline$p$ value & \multicolumn{2}{|c|}{$<0.0001$ (H.S.) } & \multicolumn{2}{|c|}{$<0.0566$ (N.S.) } & \multicolumn{2}{|c|}{$<0.0001$ (H.S.) } \\
\hline
\end{tabular}

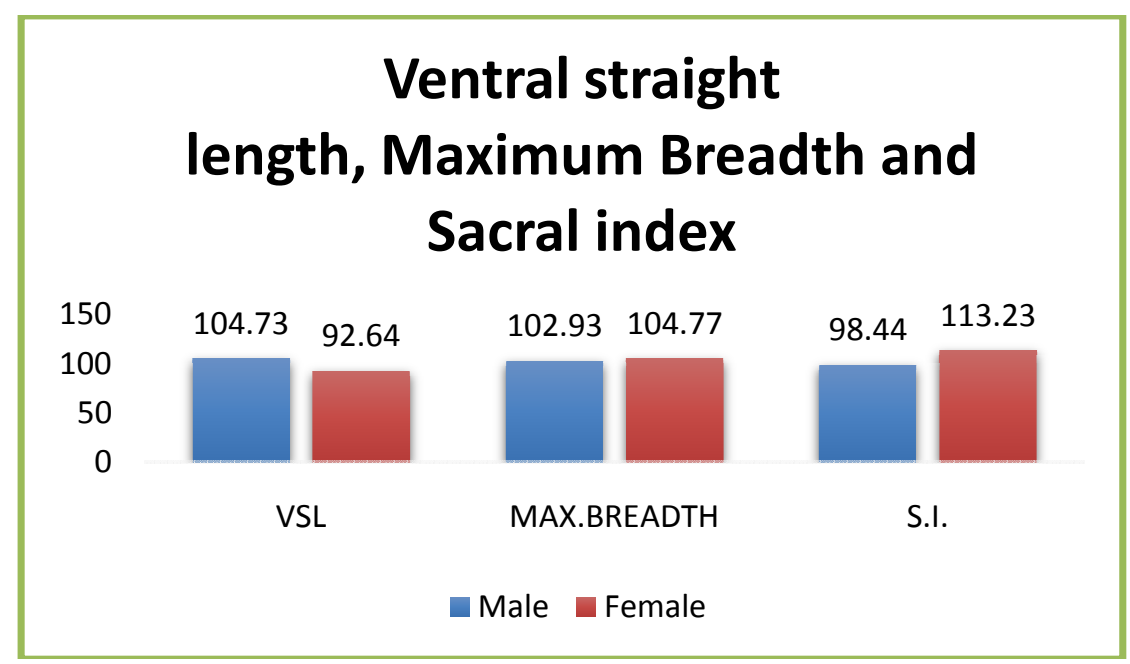

Figure 1: Showing measurements of all three parameters 


\section{DISCUSSION}

\begin{tabular}{|c|c|c|c|c|c|c|c|c|c|c|}
\hline \multirow{2}{*}{$\begin{array}{l}\text { Sr. } \\
\text { No. }\end{array}$} & \multirow{2}{*}{ INVESTIGATORS } & \multicolumn{4}{|c|}{ MALE } & \multicolumn{4}{|c|}{ FEMALE } & \multirow{2}{*}{$\begin{array}{c}\text { SSD } \\
P\end{array}$} \\
\hline & & $\mathbf{N}$ & $x$ & RANGE & S.D. & $\mathbf{N}$ & $\mathrm{x}$ & RANGE & S.D. & \\
\hline 1 & $\begin{array}{l}\text { Arora et al } \\
\quad-2010\end{array}$ & 40 & 109.74 & - & 11.66 & 40 & 91.22 & - & 6.348 & $<0.0001$ \\
\hline 2 & $\begin{array}{c}\text { Shailaja et al } \\
-2010\end{array}$ & 190 & 11 & $\begin{array}{l}8.2- \\
13.3\end{array}$ & 0.84 & 64 & 9.45 & $8.2-11.1$ & 0.85 & $<0.001$ \\
\hline 3 & $\begin{array}{l}\text { Sachdeva } \\
-2011\end{array}$ & 40 & 10.41 & $\begin{array}{l}6.82- \\
13.12\end{array}$ & 1.26 & 10 & 9.18 & $\begin{array}{l}8.31- \\
10.70\end{array}$ & 0.71 & $<0.005$ \\
\hline 4 & $\begin{array}{l}\text { Mazumdar } \\
\text { et al (2012) }\end{array}$ & 127 & 100.8 & $\begin{array}{l}66.3- \\
135.3\end{array}$ & 11.5 & 123 & 87.3 & $\begin{array}{l}65.1- \\
109.5\end{array}$ & 7.4 & $<0.001$ \\
\hline 5 & Present study & 25 & 104.73 & $\begin{array}{l}90.35- \\
120.78\end{array}$ & 5.94 & 25 & 92.64 & $\begin{array}{c}81- \\
110.64\end{array}$ & 6.1 & $<0.0001$ \\
\hline
\end{tabular}

$\mathrm{N}=$ Sample size, $\mathrm{X}=$ Mean, S.D.= Standard deviation, $\mathrm{p}=$ Probability, N.S.= Not significant, S.S.D= Statistically significant difference between two sexes

Table 3: Maximum breadth

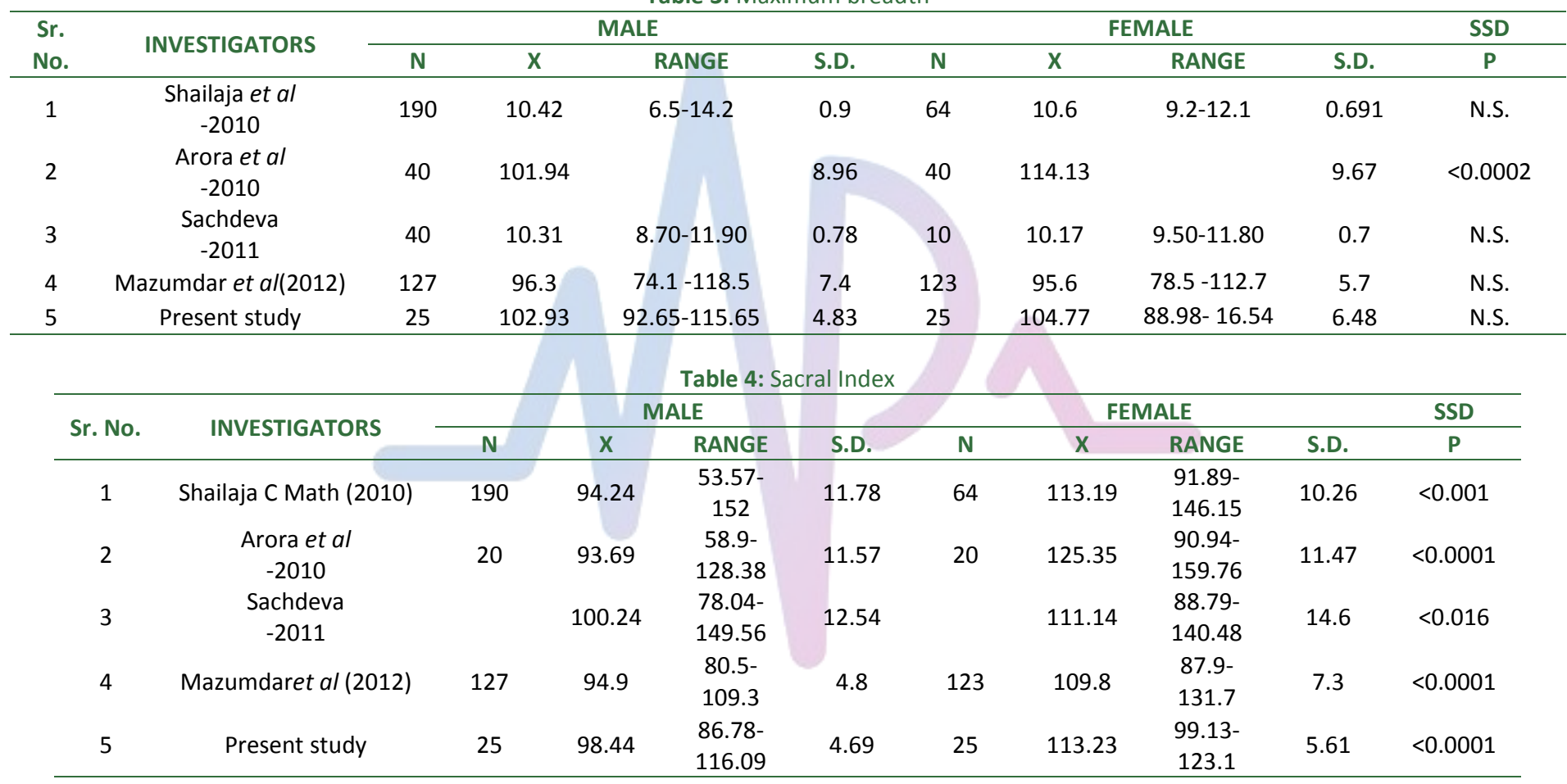

Various studies of different authors were compared with present study for all three parameters are shown in Table 2,3 and 4.

\section{CONCLUSION}

The mean value for ventral straight length was found to be $104.73 \mathrm{~mm}$ in males and $92.64 \mathrm{~mm}$ in females and was statistically highly significant. The study is correlated with Raju et al and Sachdeva et al. The mean value for maximum breadth found to be $102.93 \mathrm{~mm}$ in males and $104.77 \mathrm{~mm}$ in females and was statistically not significant. $0 \%$ of bones were identified by using this parameter. The findings of present study correlated with study done by Raju et al and Sachdeva et al. The mean value for sacral index found to be $98.44 \mathrm{~mm}$ in males and $113.23 \mathrm{~mm}$ in females. $57.9 \%$ of bones in females and $27.71 \%$ of bones in males were identified by using this parameter. This is most significant parameter for sex determination. Similar findings were reported by other research workers such as Mishra et al, Shailaja et al, Patel. Anatomists and anthropologists since long acknowledged the importance of sacrum in identifying the sex of a deceased person. The present study was undertaken to find out similarities and differences in the 
metrical values of different sacral parameters in males and females and also highlight the best parameter which can be used for sexual dimorphism of sacrum.

\section{REFERENCES}

1. Arora AK, Gupta P, Mahajan S, Kapoor SS. Significance of sacral index in estimation of sex in sacra of cadavers in Punjab. J. Indian Acad Forensic Med. 2010; 32(2):104107.

2. Standring S, editor. Gray's Anatomy.40th Edition. Spain: Churchill Livingstone Elsevier; 2008.

3. Kothapalli J, Velichety SD, Desai V, Zammer MR. Morphometric study of sexual dimorphism in adult sacra of south Indian population. Int J Bio Med Res.2012; 3(3):2076-2081.

4. Mamatha H, Sandhya, Sushma RK, Suhani S, Naveen K. Significance of various sacral measurements in the determination of sex in south Indian population. Int J Cur Res Rev.oct 2012; 4(20):112-118.

5. Mazumdar S, Ray A, Mazumdar A, Mazumdar S, Sinha A, Vasisht S. Sexual dimorphism and regional difference in size of sacrum: A study in Eastern India. Al Ameen J Med Sci 2012; 5(3):298-307.

6. Mustafa MS, Mahmoud OM, Raouf HHA, Atef HM. Morphometric study of sacral hiatus in adult human Egyptian sacra: Their significance in caudal epidural anaesthesia. Saudi Journal of Anaesthesia.2012; 6(4):350-357.

7. Patel ZK, Thummar B, Rathod SP, Singel TC, Patel S, Zalawadia A. Multicentric Morphometric study of dry human sacrum of Indian population in Gujrat Region. NJIRM 2011; 2(2):31-35
8. Rongming $\mathrm{Xu}, \mathrm{MD}$, Nabil A. Ebraheim, Nicholas K. Gove, MD.Surgical anatomy of the sacrum. Am J Orthop.208; 37(10): E177-E181.

9. Sachdeva K, Singla RK, Kalsey G, Sharma G. Role of sacrum in sexual dimorphism- A morphometric study. J.IndianAcad Forensic Med. 2011; 33(3):206-210.

10. Bhattacharya S, Majumdar S, Chakraborty P, Mazumdar S, Mazumdar A. A morphometric study of sacral hiatus for caudal epidural block among the population of West Bengal. Indian Journal of Basic and applied Medical Research; 2013; 2(7):660-667.

11. The sacrum - the holy bone April 2013. Available from www.medicinenet.com/script/main/art.asp?articlekey $=69$ 70

12. Vijisha Phalgunan, Baskaran S. Morphometric analysis of sacral hiatus and its clinical significance. The Health Agenda.2013; vol1(1):10-15.

13. Shilpa Nilesh Shewale, Mohammad Laeeque, P.R. Kulkarni, Chaya Vijay Diwan. Morphological and morphometrical study of sacral hiatus. International journal of recent trends in science and technology 2013; 6(1):48-52.

14. Shree Krishna HK, Yatraj S, Vijaya Kumari. Credibility of various Indices of sacrum in identification of sex of sacrum. International Journal of Medical Toxicology and Forensic Medicine.2013; 3(2):58-63.

15. Patil Dhananjay S, Jadhav Hrishikesh R, Binod Kumar, Mehta CD, Patel Vipul D. Anatomical study of sacral hiatus for caudal epidural block. National Journal of Medical Research.2012; 3(2):272-275.

16. Lakshmi Trikkur Anantharaman, AzraJabeen. Surgically relevant morphometry of sacral hiatus. Anatomica Karnataka.2013; 7(1):52-56.
Source of Support: None Declared
Conflict of Interest: None Declared 